\title{
Pelatihan Penggunaan KIT IPA dan Pengembangan LKPD Berbasis Praktikum untuk Guru IPA
}

\author{
Usmeldi $^{1 *}$, Risda Amini ${ }^{2}$ \\ ${ }^{1}$ Pendidikan Teknik Elektro, Fakultas Teknik, Universitas Negeri Padang \\ ${ }^{2}$ Pendidikan Guru Sekolah Dasar, Fakultas Ilmu Pendidikan, Universitas Negeri Padang \\ *usmeldy@yahoo.co.id
}

\begin{abstract}
Abstrak
Praktikum merupakan bagian terpenting dari pembelajaran IPA karena IPA berdasarkan gejala fisis pada kehidupan sehari-hari. Setiap topik pembelajaran IPA seharusnya diajarkan melalui praktikum atau demonstrasi yang dilakukan di laboratorium. Di sekolah negeri, umumnya banyak rombongan belajar, sehingga menyulitkan guru menjadwalkan kegiatan praktikum. Komponen Instrumen Terpadu (KIT) menjadi salah satu solusi untuk keterbatasan alat di laboratorium. KIT praktikum berupa seperangkat alat praktikum yang dikemas sedemikian rupa dalam kotak yang berisi alat-alat praktikum. Hasil survei awal di sekolah mitra menunjukkan bahwa: (1) Guru kesulitan menggunakan KIT praktikum IPA. (2) Laboratorium dan KIT praktikum IPA sudah tersedia di sekolah. (3) Guru kesulitan dalam mengembangkan lembar kerja peserta didik (LKPD). (4) Pemanfaatan laboratorium IPA masih kurang, karena bidang keahlian guru IPA adalah pendidikan fisika dan pendidikan biologi. Tujuan kegiatan program kemitraan masyarakat (PKM) adalah untuk meningkatkan kemampuan guru IPA dalam menggunakan KIT praktikum dan mengembangkan LKPD berbasis praktikum sesuai dengan alat yang tersedia di KIT IPA. Metode pelaksanaan kegiatan adalah metode ceramah, diskusi, demonstrasi, dan praktik. Instrumen pengumpul data kegiatan berupa angket, lembar observasi, dan lembar penilaian LKPD. Hasil kegiatan PKM menunjukkan bahwa keterampilan peserta pelatihan menggunakan KIT praktikum IPA termasuk kategori baik. Kemampuan mengembangkan LKPD termasuk kategori baik. LKPD yang dihasilkan termasuk kategori baik.
\end{abstract}

Kata kunci: IPA, KIT, LKPD, Praktikum.

\section{PENDAHULUAN}

Keterampilan proses sain perlu dilatih kepada peserta didik untuk menjelajahi dan memahami alam sekitar. Pembelajaran IPA seharusnya melatih keterampilan proses sain untuk mengembangkan keterampilan observasi, merencanakan penyelidikan, menginterpretasi data, dan menyimpulkan. Keterampilan proses sains dapat dilatih melalui kegiatan laboratorium atau praktikum. Praktikum merupakan bagian terpenting dari pembelajaran IPA karena IPA berdasarkan gejala fisis pada kehidupan sehari-hari. Pada mata pelajaran IPA, konsep dan subkonsep dipelajari melalui penelitian sederhana, percobaan, dan sejumlah kegiatan untuk mengembangkan keterampilan proses. Hakikat IPA adalah proses penemuan. Setiap topik pembelajaran IPA seharusnya diajarkan melalui percobaan atau demonstrasi yang dilakukan di laboratorium.

Pembelajaran praktikum memiliki banyak keunggulan, antara lain pembelajaran praktikum memberikan pengalaman bagi peserta didik untuk mengobservasi dan memahami fenomena alam (Hasruddin \& Rezeqi, 2012). 
Pembelajaran IPA melalui praktikum dapat membantu peserta didik mengaitkan dua domain pengetahuan, yaitu domain obyek nyata yang dapat diamati dan domain pengetahuan pikiran (Murniati \& Yusup, 2015). Dengan demikian dalam kegiatan laboratorium peserta didik menghubungkan hasil pengamatannya dengan pengetahuan atau teori yang dimilikinya.

Guru berupaya mewujudkan penerapan pembelajaran praktikum dengan menggunakan Lembar Kerja Peserta Didik (LKPD) yang sudah tersedia di sekolah. Analisis terhadap LKPD yang ada di sekolah menemukan bahwa masih banyak kekurangan dalam menghadirkan obyek atau fenomena yang relevan. Kekurangan tersebut disebabkan oleh (1) prosedur yang kurang tepat, (2) alat dan bahan yang kurang relevan, dan (3) waktu kegiatan yang terlalu lama. Menurut guru, pembelajaran dengan metode praktikum disenangi oleh peserta didik dan lebih bermakna. Guru mengungkapkan kelemahan pembelajaran praktikum adalah waktu dan ketersediaan alat yang terbatas. Di sekolah negeri, umumnya banyak rombongan belajar, sehingga menyulitkan guru menjadwalkan kegiatan praktikum.

Komponen Instrumen Terpadu (KIT) praktikum menjadi salah satu solusi untuk keterbatasan alat di sekolah. KIT praktikum berupa seperangkat alat praktikum yang dikemas sedemikian rupa dalam kotak yang berisi alat-alat praktikum. Menurut guru, keberadaan KIT praktikum memudahkan guru saat pembelajaran, karena praktis dan disediakan petunjuk bagi guru untuk praktikum yang akan dilakukan. Jenis percobaan yang dapat dilaksanakan dengan KIT IPA telah disesuaikan dengan kurikulum 2013. Guru berpendapat bahwa KIT praktikum yang tersedia di sekolah terbatas pada materi-materi tertentu. KIT praktikum yang tersedia di sekolah memiliki konten IPA secara parsial pada bidang Kimia, Fisika, Biologi, dan Ilmu Pengetahuan Bumi dan Antariksa (IPBA).

KIT praktikum IPA merupakan salah satu alat praktikum yang dapat digunakan dalam pembelajaran di kelas. Pelaksanaan praktikum IPA dengan KIT praktikum menjadi lebih mudah dan dapat mengurangi risiko kecelakaan laboratorium. Selain itu, memungkinkan pelaksanaan mobile experiment karena peralatan praktikum yang bersifat portable. Sementara bagi laboran, penggunaan peralatan KIT praktikum memudahkan tata kelola peralatan, baik tata kelola penyimpanan, maupun administrasinya. Keuntungan bagi pengelola institusi, penggunaan KIT praktikum mereduksi biaya pelaksanaan praktikum, baik dalam pengadaan peralatan, bahan, dan prasarana praktikum (Putri \& Widodo, 2018). Dalam melakukan praktikum dengan KIT praktikum diperlukan petunjuk agar praktikum itu dapat berjalan dengan baik dan dapat dimengerti oleh peserta didik. Petunjuk praktikum berupa LKPD yang berisi petunjuk yang memudahkan peserta didik dalam melakukan praktikum menggunakan KIT praktikum. LKPD disesuaikan dengan materi yang ada dalam KIT praktikum.

Berbagai penelitian menunjukkan bahwa penggunaan KIT IPA sangat membantu dalam pembelajaran, dapat meningkatkan hasil belajar peseta didik (Rosidah \& Rosdiana, 2019). Hasil penelitian Satria \& Sari (2018) menunjukkan bahwa penggunaan KIT IPA adalah salah satu faktor yang mempengaruhi pembelajaran IPA. Hasil penelitian Rosidah \& Rosdiana (2019) menunjukkan bahwa penggunaan KIT IPA membuat guru menjadi lebih percaya diri dalam mengajarkan materi IPA. Meskipun dianggap sangat penting dalam pengajaran 
IPA, hasil penelitian Rosidin, Maulina \& Suane (2020) menunjukkan bahwa salah satu masalah yang ditemui guru dalam melaksanakan praktikum adalah guru tidak tahu cara menggunakan alat-alat praktikum. Guru belum paham menggunakan KIT IPA dan hal ini membuat tingkat keterlaksanaan kegiatan praktikum menjadi rendah (Budiyanto, Setiawan \& Erman, 2016).

Hasil survei awal yang telah dilakukan oleh tim pengabdi di sekolah mitra dan SMP lainnya di kabupaten Agam menunjukkan bahwa: (1) Guru belum memahami dengan baik materi dan pembelajaran IPA terpadu beserta langkahlangkah pengembangan pembelajarannya. (2) Guru kesulitan dalam mengembangkan LKPD IPA. (3) Guru kesulitan menggunakan KIT praktikum IPA. (4) Laboratorium dan KIT praktikum IPA sudah tersedia di sekolah. (5) Pemanfaatan laboratorium IPA di sekolah masih kurang. Berbagai hal menjadi kendala pelaksanaan praktikum, antara lain latar belakang guru yang berasal dari pendidikan fisika dan biologi, guru yang kurang mengetahui cara menggunakan alat laboratorium, dan tidak adanya petugas laboratorium (laboran) yang berfungsi untuk mengelola laboratorium IPA. Berdasarkan analisis situasi maka tim pengabdi bersama mitra menetapkan prioritas masalah yang akan ditanggulangi dengan segera, yaitu melaksanakan kegiatan pelatihan dan pendampingan penggunaan KIT praktikum IPA dan mengembangkan LKPD IPA untuk guru IPA di sekolah mitra dan SMP Negeri di kabuparten Agam yang tergabung dalam musyawarah guru mata pelajaran (MGMP) IPA. Tujuan kegiatan program kemitraan masyarakat (PKM) ini adalah untuk meningkatkan kemampuan guru IPA dalam menggunakan KIT praktikum dan mengembangkan LKPD berbasis praktikum sesuai dengan alat yang tersedia di KIT praktikum.

\section{METODE PELAKSANAAN}

Metode yang digunakan adalah metode yang dapat mengkondisikan seluruh peserta untuk terlibat aktif dalam pelatihan, berupa metode ceramah, diskusi, demonstrasi, dan praktik. Pelatihan dilaksanakan di SMP Negeri 1 Ampek Angkek pada setiap hari Sabtu sesuai dengan jadwal kegiatan MGMP IPA SMP di kabupaten Agam wilayah timur. Waktu pelatihan dialokasikan dengan proporsi $20 \%$ untuk teori (penjelasan materi pelatihan) dan $80 \%$ untuk praktik (penggunaan KIT praktikum IPA).

Langkah-langkah kegiatan pelatihan adalah sebagai berikut: (1) melakukan diskusi untuk mengetahui pengetahuan awal peserta pelatihan tentang penguasaan materi IPA; (2) melakukan diskusi untuk mengetahui pengetahuan awal peserta pelatihan tentang penggunaan KIT praktikum IPA; (3) memberikan penjelasan tentang materi praktikum IPA; (4) memberikan penjelasan tentang penggunaan KIT praktikum IPA; (5) membimbing peserta pelatihan menggunakan KIT praktikum IPA; (6) membimbing peserta pelatihan mengembangkan LKPD yang sesuai dengan KIT praktikum IPA; (7) peserta pelatihan melakukan uji coba LKPD pada peserta didik SMP; (8) mengevaluasi proses kegiatan pelatihan; dan (9) mengevaluasi hasil kegiatan pelatihan berupa LKPD IPA.

Data kegiatan PKM dikumpulkan melalui instrumen evaluasi yang mencakup evaluasi proses dan hasil kegiatan. Instrumen berupa angket, lembar observasi, dan lembar penilaian LKPD. 


\section{HASIL DAN PEMBAHASAN \\ Hasil}

Kegiatan Program Kemitraan Masyarakat (PKM) guru IPA SMP kabupaten Agam berupa pelatihan menggunakan KIT praktikum IPA dan pendampingan pengembangan Lembar Kerja Peserta Didik (LKPD) bagi guru IPA yang tergabung dalam MGMP IPA SMP Negeri di kabupaten Agam wilayah Timur. Sebelum penyajian materi pelatihan dilakukan penjajagan (braimstorming) untuk mengetahui kemampuan awal peserta PKM melalui angket dan diskusi. Hasil penjajagan menunjukkan bahwa sebagian besar peserta belum terampil menggunakan KIT praktikum IPA. Selama ini peserta pelatihan belum menggunakan KIT praktikumIPA. Data selengkapnya disajikan dalam Tabel 1.

Tabel 1. Pengetahuan Awal Peserta Pelatihan

\begin{tabular}{|c|c|c|c|c|c|}
\hline \multirow{2}{*}{ No. } & \multirow{2}{*}{ Pernyataan } & \multicolumn{4}{|c|}{ Jumlah Respon } \\
\hline & & TS & KS & $\mathbf{S}$ & SS \\
\hline 1 & $\begin{array}{l}\text { Saya memperoleh pengetahuan menggunakan KIT } \\
\text { praktikum IPA secara mandiri }\end{array}$ & 16 & 10 & 4 & 0 \\
\hline 2 & $\begin{array}{l}\text { Saya memperoleh pengetahuan menggunakan KIT } \\
\text { praktikum IPA melalui pelatihan. }\end{array}$ & 19 & 9 & 2 & 0 \\
\hline 3 & $\begin{array}{l}\text { Saya memperoleh pengetahuan menggunakan KIT } \\
\text { praktikum IPA pada saat kuliah S1 }\end{array}$ & 8 & 17 & 5 & 0 \\
\hline 4 & $\begin{array}{l}\text { Saya sudah mengembangkan / menyusun LKPD (Lembar } \\
\text { Kerja Peserta Didik) menggunakan KIT praktikum IPA }\end{array}$ & 10 & 18 & 2 & 0 \\
\hline 5 & $\begin{array}{l}\text { Saya sudah menggunakan KIT praktikum IPA di } \\
\text { laboratorium / kelas }\end{array}$ & 10 & 19 & 1 & 0 \\
\hline 6 & KIT praktikum IPA sudah tersedia di sekolah saya & 0 & 0 & 0 & 30 \\
\hline 7 & Saya belum memahami penggunaan KIT praktikum IPA & 0 & 9 & 17 & 4 \\
\hline 8 & Saya belum pernah menggunakan KIT praktikum IPA & 0 & 5 & 25 & 0 \\
\hline 9 & $\begin{array}{l}\text { Kegiatan praktikum IPA sudah dilaksanakan di sekolah } \\
\text { saya }\end{array}$ & 5 & 17 & 8 & 0 \\
\hline 10 & Saya belum memahami materi praktikum IPA & 0 & 11 & 17 & 2 \\
\hline 11 & $\begin{array}{l}\text { Jumlah KIT praktikum IPA di sekolah saya tidak cukup } \\
\text { bila dibandingkan dengan jumlah peserta didik per kelas }\end{array}$ & 0 & 0 & 25 & 5 \\
\hline 12 & Saya belum memahami pengembangan LKPD & 0 & 7 & 13 & 10 \\
\hline 13 & $\begin{array}{l}\text { Sistematika LKPD yang digunakan dalam praktikum IPA } \\
\text { sudah sesuai dengan kurikulum } 2013\end{array}$ & 3 & 15 & 5 & 2 \\
\hline 14 & $\begin{array}{l}\text { Saya kesulitan menggunakan KIT praktikum IPA karena } \\
\text { latar belakang pendidikan yang tidak relevan }\end{array}$ & 0 & 15 & 12 & 3 \\
\hline
\end{tabular}

Keterangan: Tidak Setuju (TS), Kurang Setuju (KS), Setuju (S), Sangat Setuju (SS).

Berdasarkan hasil penjajagan seperti pada tabel 1 maka kegiatan diprioritaskan untuk melatih peserta menggunakan KIT praktikum IPA dan mengembangkan LKPD IPA. Setelah pembukaan oleh kepala SMP Negeri 1 Ampek Angkek dan braimstorming, acara dilanjutkan dengan penyajian materi tentang penggunaan KIT IPA selama 90 menit (gambar 1). Setelah materi selesai disampaikan, dilanjutkan dengan praktikum menggunakan KIT IPA secara berkelompok (gambar 2). Peserta pelatihan sangat antusias mempelajari materi pelatihan yang 
diberikan. Hal ini terlihat dari awal hingga akhir kegiatan, semua peserta mengikuti dengan baik. Semua peserta pelatihan berpartisipasi dalam melaksanakan praktikum, sehingga praktikum berjalan dengan lancar. Pada kegiatan praktikum terlihat bahwa kemampuan peserta pelatihan dalam menggunakan KIT IPA tidak sama. Masih banyak peserta pelatihan yang perlu bimbingan menggunakan KIT IPA. Dalam kegiatan praktikum menggunakan KIT IPA, peserta pelatihan dibimbing oleh mahasiswa S2 Pendidikan Fisika, FMIPA Universitas Negeri Padang.

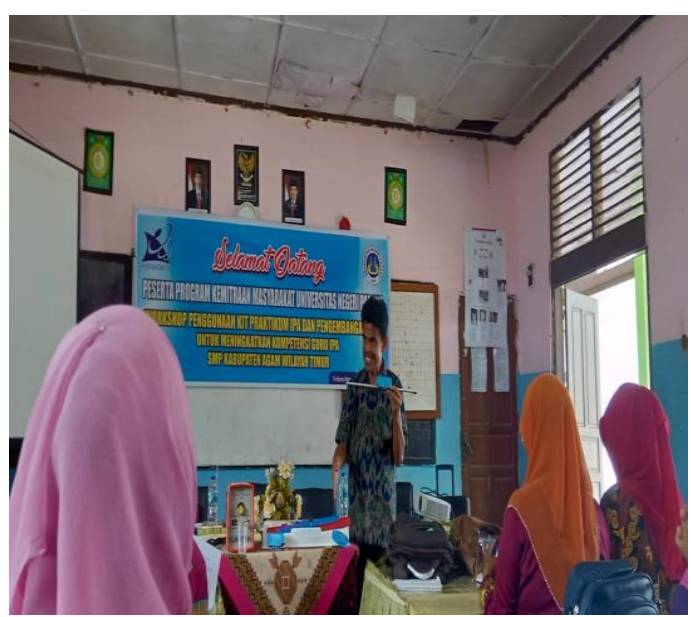

Gambar 1. Penjelasan penggunaan KIT IPA

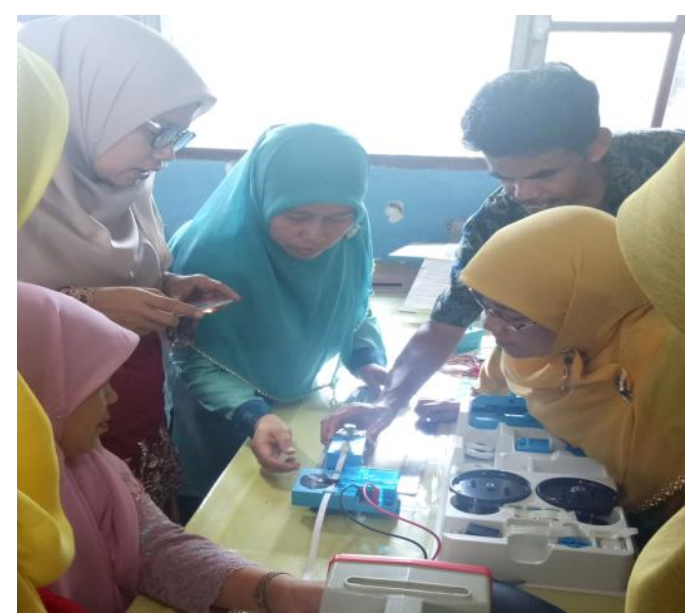

Gambar 2. Instruktur Mendampingi Peserta Menggunakan KIT IPA

Pelaksanaan kegiatan pendampingan dapat berjalan dengan baik dan lancar. Hal ini dapat dilihat dari partisipasi aktif peserta dan kerjasama tim pelaksana kegiatan. Pelaksanaan kegiatan ini dapat membantu peserta pelatihan dalam menggunakan KIT praktikum IPA dan mengembangkan LKPD IPA. Pencapaian hasil pelaksanaan kegiatan pendampingan dapat dilihat dari aspek tujuan dan manfaat pelaksanaan kegiatan. Tujuan kegiatan yang telah ditetapkan yaitu peserta pelatihan mampu menggunakan KIT praktikum IPA dan mengembangkan LKPD IPA, sudah dicapai dengan baik. Peserta pelatihan sudah memiliki keterampilan menggunakan KIT praktikum IPA dan kemampuan mengembangkan LKPD IPA.

Tabel 2. Hasil Penilaian Kegiatan PKM

\begin{tabular}{ccc}
\hline No. & Aspek yang dinilai & Rata-rata \\
\hline 1 & Kemampuan memahami materi praktikum IPA & Baik \\
2 & Kemampuan memahami KIT praktikum IPA & Baik \\
3 & Keterampilan menggunakan KIT praktikum IPA & Baik \\
4 & Kemampuan menguasai pengembangan LKPD & Baik \\
5 & Kemampuan membuat LKPD menggunakan KIT IPA & Baik \\
6 & LKPD yang dihasilkan & Baik \\
\hline
\end{tabular}

Target dari pelaksanaan kegiatan ini berupa pembuatan LKPD IPA. Hasil program pendampingan ini dapat memberikan dampak terhadap peningkatan keterampilan peserta pelatihan menggunakan KIT praktikum IPA dan mengembangkan LKPD, serta kemampuan peserta pelatihan dalam melaksanakan 
praktikum IPA. Setelah mengikuti kegiatan ini guru mampu menggunakan KIT praktikum IPA dan mengembangkan LKPD IPA. Keberhasilan pelaksanaan kegiatan pelatihan dan pendampingan dapat dilihat dari aspek penguasaan terhadap materi pelatihan, keterampilan menggunakan KIT IPA, dan kemampuan membuat LKPD IPA. Hasil penilaian pelaksanaan kegiatan PKM disajikan dalam Tabel 2.

Pada akhir kegiatan dilakukan penjaringan tanggapan peserta menggunakan angket sebagai upaya mengetahui kesulitan dan pendapat peserta pelatihan tentang kegiatan yang telah dilakukan. Hasil tanggapan peserta pelatihan atas kegiatan yang telah dilakukan adalah:

1. Pelatihan sangat bermanfaat dan dapat meningkatkan pengetahuan dan keterampilan peserta dalam menggunakan KIT praktikum IPA dan mengembangkan lembar kerja peserta didik. Diharapkan penerapan LKPD berbasis praktikum dapat memotivasi peserta didik untuk belajar lebih baik.

2. Materi pelatihan dapat diterapkan dalam pembelajaran IPA.

3. Peserta pelatihan menyarankan supaya pelatihan dilanjutkan untuk materi dan pembelajaran IPA lainnya, misalnya pelatihan mengembangkan perangkat pembelajaran IPA dengan model atau metode pembelajaran tertentu.

Hasil uji coba LKPD pada peserta didik menunjukkan bahwa peserta didik dapat menggunakan LKPD secara mandiri dan dapat membangkitkan motivasi belajar peserta didik. Hasilnya selengkapnya disajikan pada Tabel 3.

Tabel 3. Tanggapan Peserta Didik terhadap LKPD berbasis Praktikum

\begin{tabular}{clcccc}
\hline \multirow{2}{*}{ No. Pernyataan } & \multicolumn{3}{c}{ Persentase Respon (\%) } \\
\cline { 2 - 6 } & TS & KS & S & SS \\
\hline 1 & $\begin{array}{l}\text { Saya tidak mengalami kesulitan menggunakan } \\
\text { LKPD pada mata pelajaran IPA }\end{array}$ & 0 & 93 & 7 \\
2 & $\begin{array}{l}\text { Saya mudah memahami pelajaran IPA } \\
\text { menggunakan LKPD }\end{array}$ & 0 & 0 & 88 & 12 \\
3 & $\begin{array}{l}\text { Saya cepat mengingat materi pelajaran IPA dengan } \\
\text { menggunakan LKPD }\end{array}$ & 0 & 0 & 78 & 22 \\
4 & $\begin{array}{l}\text { Pembelajaran IPA dengan menggunakan LKPD } \\
\text { membuat saya puas }\end{array}$ & 0 & 84 & 16 \\
5 & $\begin{array}{l}\text { Pembelajaran IPA dengan LKPD sangat bermanfaat } \\
\text { Dengan LKPD saya dapat belajar IPA sesuai secara } \\
\text { mandiri }\end{array}$ & 0 & 0 & 84 & 16 \\
7 & $\begin{array}{l}\text { Langkah-langkah kegiatan dalam LKPD dapat } \\
\text { dilaksanakan }\end{array}$ & 0 & 0 & 97 & 3 \\
8 & Kalimat dalam LKPD disajikan secara sederhana & 0 & 0 & 91 & 9 \\
\hline Keterangan: Tidak Setuju (TS), Kurang Setuju (KS), Setuju (S), Sangat Setuju (SS).
\end{tabular}

Salah satu hasil pengembangan LKPD oleh peserta pelatihan disajikan dalam Gambar 3 dan Gambar 4. 


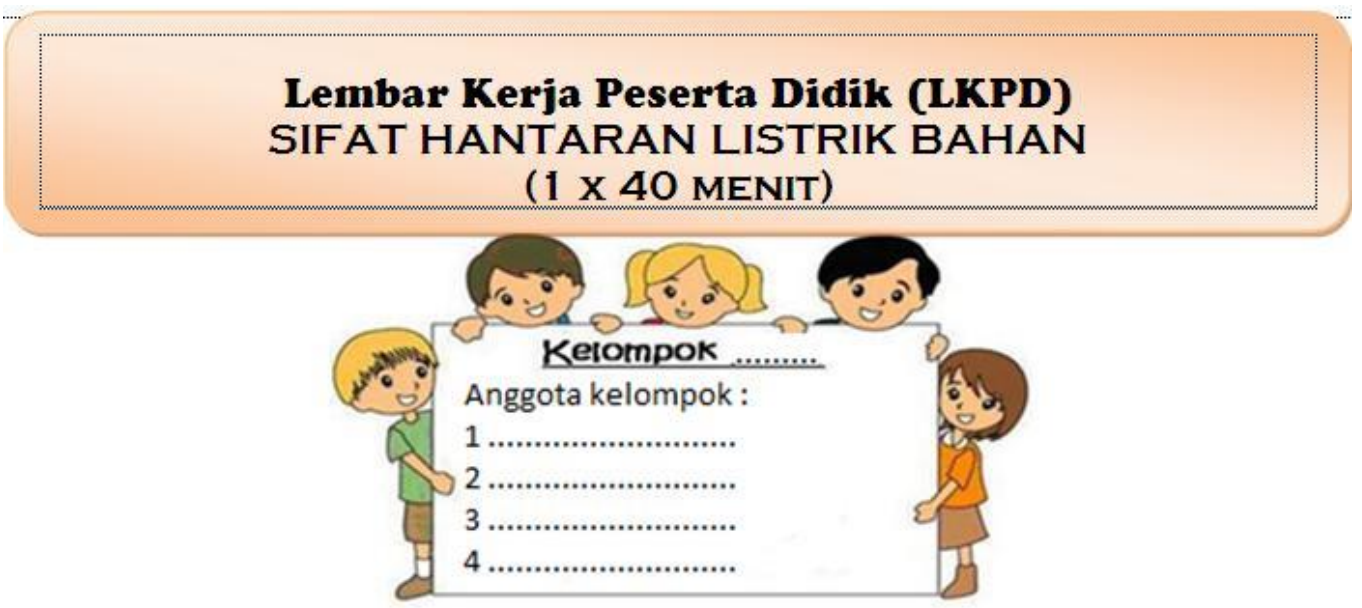

Gambar 3. Cover LKPD

\section{E) LANGKAHKERJA}

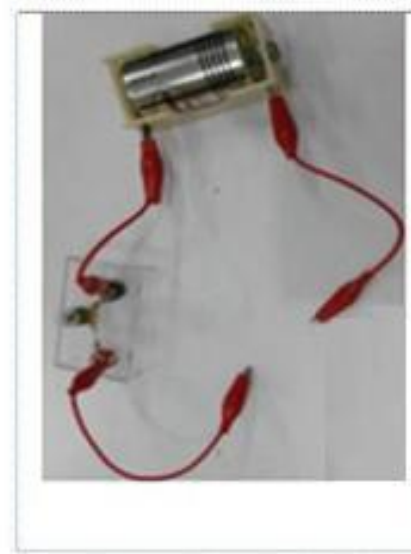

1. Susunlah alat seperti pada gambar di samping

2. Sambungkanlah salah satu bahan yang diberikan seperti kayu (pensil) dengan menggunakan kabel yang dilengkapi penjepit buaya

3. Amatilah nyala lampu yang terjadi. Catatlah hasil pengamatanmu ke dalam tabel yang disediakan

4. Ulangi kegiatan pada langkah $1 \mathrm{~s} / \mathrm{d} 3$ dengan menggunakan bahan yang berbeda

Gambar 4. Langkah keja di LKPD

\section{Pembahasan}

Berdasarkan hasil kegiatan pelatihan dan uji coba produk yang dilakukan pada peserta didik ditemukan bahwa kesiapan guru, peserta didik, dan fasilitas sangat menentukan keberhasilan pelaksanaan pembelajaran, khususnya penerapan LKPD. Dari sisi guru, kemampuan mengusai materi praktikum IPA yang beragam merupakan faktor yang penting dicermati. Dari sisi peserta didik ditemukan bahwa seluruh peserta didik sudah mampu menggunakan LKPD, sehingga pelaksanaan uji coba dapat berjalan dengan lancar. KIT IPA efektif untuk meningkatkan hasil belajar siswa (Nurfiyanti, 2017). Dari sisi fasilitas, kelengkapan fasilitas laboratorium IPA yang dimiliki sekolah mitra cukup mendukung untuk pelaksanaan uji coba LKPD yang dihasilkan oleh peserta pelatihan. Kegiatan pelatihan memberikan manfaat pada peserta, yaitu dapat memberikan pengetahuan tentang penggunaan KIT IPA dalam pembelajaran berbasis praktikum sebagaimana juga ditemukan oleh Wirawan dkk. (2021). Peserta pelatihan mampu mengembangkan LKPD berbasis praktikum dengan KIT 
IPA sebagaimana juga ditemukan oleh Qary (2017), Chania (2018), Manurung \& Sinambela (2018), Hariningwang \& Fitrihidajati (2020).

Hasil pelatihan menunjukkan adanya peningkatan kemampuan dan keterampilan peserta (guru IPA) dalam menggunakan KIT IPA dan peningkatan kemampuan guru untuk mensinergikan pembelajaran dengan penggunaan KIT IPA sebagaimana juga ditemukan oleh Khair dkk. (2021). Pelatihan KIT IPA dapat meningkatkan pengetahuan dan keterampilan para peserta tentang KIT IPA (Alwi dkk., 2020; Rapi, Rachmawati \& Widiarini, 2020; Sukarjita (2020). Guru telah menyadari bahwa penggunaan KIT IPA sangat membantu guru dalam pembelajaran IPA dan dapat dijadikan media dalam mencapai tujuan pembelajaran IPA. Pelatihan penggunaan KIT mampu meningkatkan keterampilan guru IPA dalam merakit rangkaian dengan menggunakan KIT untuk menunjang pembelajaran IPA (Muthmainnah, Aminah \& Nurmina, 2016; Laili, 2019).

Pembelajaran praktikum menggunakan KIT IPA dapat dilakukan secara individual dan kelompok. Dalam hal ini peserta didik langsung berhadapan dengan peralatan laboratorium untuk mempelajari materi atau kompetensi yang ditetapkan. Respon peserta didik terhadap LKPD sangat setuju untuk mendukung kegiatan praktikum. Hal ini sejalan dengan temuan Ali (2009) yang menyatakan bahwa respon peserta didik terhadap LKPD sangat baik untuk mendukung belajar mandiri atau kelompok. Di samping itu peserta didik merasa puas dan senang dalam pembelajaran dengan menggunakan LKPD berbasis praktikum, sebagaimana juga ditemukan oleh Wibowo (2013).

\section{SIMPULAN}

Kegiatan Program Kemitraan Masyarakat dilaksanakan berupa pelatihan penggunaan Komponen Instrumen Terpadu (KIT) praktikum IPA dan pengembangan Lembar Kerja Peserta Didik (LKPD). Kegiatan pelatihan mampu meningkatkan pengetahuan dan keterampilan guru untuk melaksanakan kegiatan praktikum IPA sehingga dapat memotivasi peserta didik dalam belajar. Hasil evaluasi menunjukkan bahwa materi pelatihan dapat dikuasai oleh peserta pelatihan, baik pengetahuan maupun keterampilan menggunakan KIT praktikum IPA. Keberhasilan ini ditunjang oleh: (a) Adanya kesesuaian materi pelatihan dengan kebutuhan peserta. (b) Adanya respon yang positif dari peserta. (c) Sebagian besar peserta telah mempunyai keterampilan dalam menggunakan KIT praktikum IPA dan mengembangkan LKPD pada mata pelajaran IPA. Peserta didik merasa puas dan senang dalam pembelajaran IPA dengan menggunakan LKPD berbasis praktikum.

\section{UCAPAN TERIMA KASIH}

Penulis mendapat dukungan dana untuk pelaksanaan Program Kemitraan Masyarakat dari Lembaga Penelitian dan Pengabdian kepada Masyarakat (LP2M) Universitas Negeri Padang. Oleh karena itu penulis mengucapkan terima kasih kepada Ketua LP2M dan Rektor Universitas Negeri Padang. 


\section{DAFTAR PUSTAKA}

Alwi, M., Sururruddin, M., Hakim, A. R., Kudsiah, M., \& Fadilah, D. (2020). Pendampingan dan pelatihan penggunaan KIT IPA SD di gugus Tebaban. Jurnal Abdi Populika, 1(2), 54-57.

Budiyanto, M., Setiawan, B., \& Erman, E. (2016). Pendampingan pelatihan alat KIT IPA bagi guru Madrasah Tsanawiyah (MTS) kota Probolinggo untuk meningkatkan pemahaman pendekatan saintifik dalam rangka pelaksanaan kurikulum 2013. Jurnal Abdi: Media Pengabdian Kepada Masyarakat, 1(1), 78-83. https://doi.org/10.26740/ja.v1n1.p78-83

Chania, R. (2018). Pengembangan LKPD berbasis praktikum pada pembelajaran IPA di Madrasah Tsanawiyah. Natural Science: Jurnal Penelitian Bidang IPA dan Pendidikan IPA, 4(2), 664-675. https://doi.org/10.15548/nsc.v4i2.459

Hariningwang, C. N., \& Fitrihidajati, H. (2020). Profil lembar kegiatan peserta didik (LKPD) berbasis praktikum materi perubahan lingkungan dan daur ulang limbah untuk melatihkan keterampilan proses sains terintegrasi. BioEdu,9(1), 49-59.

Hasruddin, H., \& Rezeqi, S. (2012). Analisis Pelaksanaan praktikum biologi dan permasalahannya di SMA Negeri Sekabupaten Karo. Jurnal Tabularasa PPS Unimed, 9(1), 17-32.

Khair, B. N., Astria, F. P., Wardani, K. S. K., Nurwahidah, N., Sriwarthini, N. P. N., \& Rahmatih, A.N. (2021). Pelatihan dan pendampingan penggunaan KIT IPA di SD Negeri 34 Cakranegara. Jurnal Interaktif: Warta Pengabdian Pendidikan, 1(1), 14-19.

Laili, A. M. (2019). Pelatihan penggunaan KIT listrik bagi guru IPA SMP Sunan Ampel Kecamatan Karangrejo. J-Adimas (Jurnal Pengabdian Kepada Masyarakat), 7(1), 1-3. https://doi.org/10.29100/j-adimas.v7i1.1150

Manurung, S. R., \& Sinambela, M. (2018). Perangkat pembelajaran IPA berbentuk LKS berbasis laboratorium. INPAFI (Inovasi Pembelajaran Fisika), 6(1), 80-87. https://doi.org/10.24114/inpafi.v6i1.9496

Murniati, M., \& Yusup, M. (2015). Pengembangan bahan ajar mata kuliah Laboratorium Fisika Sekolah berdasarkan kompetensi. Jurnal Inovasi dan Pembelajaran Fisika, 2(2), 155-162. https://doi.org/10.36706/jipf.v2i2.2617

Muthmainnah, M., Aminah, A., \& Nurmina, N. (2016). Pelatihan penggunaan KIT IPA bagi guru sains di SD Negeri 28 Peusangan Dan Min Krueng Panjoe Kabupaten Bireuen Propinsi Aceh. Jurnal Pendidikan Dasar, 3(1), 9-12.

Nurfiyanti, N. (2017). Kelayakan KIT IPA sebagai alat praktikum pada materi energi alternatif. PENSA: E-Jurnal Pendidikan Sains, 5(03), 191-194.

Putri, N. S., \& Widodo, W. (2018). Pengembangan KIT IPA sederhana materi pemuaian untuk meningkatkan hasil belajar siwa kelas VII SMP Negeri 2 Panggul. Pensa E-Jurnal: Pendidikan Sains, 6(3). 442-446.

Qary, I. F. (2016). Pengembangan Lembar Kegiatan Siswa dan KIT IPA pada materi energi dalam sistem kehidupan untuk melatihkan keterampilan berpikir kritis siswa SMP. Pensa E-Jurnal: Pendidikan Sains, 4(3), 1-6.

Rapi, N. K., Rachmawati, D. O., \& Widiarini, P. (2020). Pelatihan media KIT IPA untuk meningkatkan profesionalisme guru-guru SMP di Buleleng. Proceeding Senadimas Undiksha, 887-896. 
Rosidah, K., \& Rosdiana, L. (2019). Efektivitas KIT rangkaian listrik sebagai media pembelajaran untuk meningkatan hasil belajar siswa SMP. PENSA: EJurnal Pendidikan Sains, 7(1). 5-9.

Rosidin, U., Maulina, D., \& Suane, W. (2020). Pelatihan pengelolaan laboratorium dan penggunaan alat peraga IPA bagi guru-guru IPA Di SMP/MTS se-kota Bandar Lampung. Jurnal Pengabdian Masyarakat MIPA dan Pendidikan MIPA,4(1), 52-60. https://doi.org/10.21831/jpmmp.v4i1. 34075

Satria, E., \& Sari, S. G. (2018). Penggunaan alat peraga dan KIT IPA oleh guru dalam pembelajaran di beberapa Sekolah Dasar di Kecamatan Padang Utara dan Nanggalo Kota Padang. IKRA-ITH HUMANIORA: Jurnal Sosial Dan Humaniora, 2(2), 1-8.

Sukarjita, I. W. (2020). Peningkatan keterampilan pengelolaan pembelajaran IPA terpadu melalui pelatihan penggunaan KIT IPA bagi guru IPA SMP di Kecamatan Kupang Barat. Jurnal Lembaga Pengabdian Kepada Masyarakat Undana, 14(2), 33-42.

Wirawan, R., Qomariyah, N., Minardi, S., Syamsuddin, S., Hiden, H., Sudiarta, W., \& Marzuki, M. (2021). Pendampingan penggunaan media pembelajaran berbasis KIT IPA untuk pembelajaran fisika di SMPN 2 Sekotong. SELAPARANG Jurnal Pengabdian Masyarakat Berkemajuan, 4(2), 353-356. https://doi.org/10.31764/jpmb.v4i2.4493 